\title{
Agricultural value chains. A bibliometric review and analysis.
}

Analuisa-Aroca, Iván Alberto. Mail: z82anari@uco.es

Department Agricultural Economics, Sociology, and Policy, Faculty of Economics and

Business Sciences, Universidad de Córdoba, Plaza de Puerta Nueva s/n, 14002

Córdoba, Spain

Jimber del Río, Juan Antonio. Mail: jjimber@uco.es

Department Agricultural Economics, Sociology, and Policy, Faculty of Economics and

Business Sciences, Universidad de Córdoba, Plaza de Puerta Nueva s/n, 14002

Córdoba, Spain

Fernández Gallardo, José Antonio. Mail: jose.fernandez@uco.es

Department Agricultural Economics, Sociology, and Policy, Faculty of Economics and

Business Sciences, Universidad de Córdoba, Plaza de Puerta Nueva s/n, 14002

Córdoba, Spain

Vergara-Romero, Arnaldo. Mail: avergarar@ecotec.edu.ec

Department of Research, Ecotec University, Samborondón-Ecuador and Espiritu Santo

\section{University, Samborondón, Ecuador}

\begin{abstract}
This work analyzes the visibility and scientific impact of publications related to agricultural value chains. The incidence of bibliometric indicators allows for the interpretation of bibliographic information generated worldwide. Objective: The objective of this research is to analyze the published literature and bibliometric indicators on agricultural value chains. The Web of Science database was used to extract value chains data. The study analyzed articles published between 2010 and 2020. The keywords used are "agricultural value chains" and articles from journals or studies related to the subject were selected for bibliometric analysis and methodological review. In the search for the keyword, a total of 4208 results were extracted, of which 1,669 records were considered for analysis. The bibliometric analysis of the data reveals that Wageningen University (55) has the highest number of publications, followed by Chinese Acad Sci (26). The author Klerkx L (9) has the highest number of records, followed by Hellin J (7). With respect to the countries with the greatest contributions on the subject are: the People's Republic of China, Germany, Italy, France and the United States. The study contributes to the analysis of bibliometrics and provides a methodological review of published journal articles on agricultural value chains. This bibliographic study presents the history of research development in agricultural value chains.
\end{abstract}

Keywords: Bioeconomy, bibliographic databases, value chains agricultural, production.

\section{Introduction}

Globalization increases and improves communication between people and places, and brings people closer together. The social, economic, environmental, political contexts change at great speed, which demands for new approaches from multiple stakeholders in performance, articulation within society and economic activities. Research shows how developed countries consume a large amount of goods and services from markets (Maier et al., 2020; Mas-Tur et al., 2019); and how agro-export processors transform the marketing channels of small economies and their income (Fabregat-Aibar et al., 2019; Sharma et al., 2018; Trapala et al., 2020).

To face the challenges posed by the sustainability of agricultural systems, the reduction of dependency links has now become a central issue within food chains and agronomic practices at different spatio-temporal and trophic levels (Janmaijaya et al., 2018), and so have the potential impacts of Covid-19 on agriculture and agricultural trade in developing countries and the IMF's economic growth forecasts for 2020-2021 (Elleby et al., 2020; Hong et al., 2019; Morton, 2020).

By choosing the topic of agricultural value chains, the researchers show interest in world food issues and contributing to meeting Goal 2 of the Sustainable Development Goals, Food and Agriculture Organization, related to Zero Hunger. (FAO, 2019). 
In addition, the strategic points of the conglomerates are considered as social, economic, environmental, ecological studies that directly and indirectly affect the formation of the value chain. Regarding the matter, there is little or no information on South American countries, so it is appropriate to generate qualitative and quantitative bibliometric indicators related to agricultural value chains. The platform allows us to quantify and compare the formation of the groups according to the research, which allows us to learn the development and progress in the different themes worldwide.

In relation to agricultural value chains, studies should be carried out in their different stages or routes of transformation of products (La Paz et al., 2020; Repanovici \& Nedelcu, 2018), while Govindan \& Soleimani (2017) mention the process of implementing and controlling the efficient and profitable flow of raw materials, inventory in process, finished products and related information from the point of consumption to the point of origin (Garrigos-Simon et al., 2018; Hasbullah et al., 2021). The different links that are formed from the production cycle to reach the consumer, through the processes of handling, transformation, sale and access to homes, have a common problem in their sector. Thus, for example, in the last decade, research has focused on the concentrations of the metal component or nanomaterials in grains or fruits and their impact on the various trophic levels (Baier-Fuentes et al., 2018; Li et al., 2019; Martinho \& Mourão, 2020).

Bibliometry — and its scientific development - is based on the search for regular statistical behaviors over time and the production of scientific information on consumption (Akinlolu et al., 2020; Ardanuy, 2009; Baranauskas et al., 2020; González-Torres et al., 2020), allowing qualitative and quantitative changes to be evaluated (De Las Heras et al., 2018). The Thomson Reuters Web of Science database is currently the main reference for scientific research worldwide (LlorentBedmar \& Sianes-Bautista, 2018). Mapping and clustering are often used in bibliometric research for the visualization of structural aspects (Lei et al., 2018; Sahle et al., 2018). The mapping technique is based on the direct application of a multidimensional scale word occurrence data matrix (Barrios Guzman et al., 2017; Malanski et al., 2020).

Bibliometry is a scientific research method that synthesizes and analyzes bibliographic material from databases that contain qualitative and quantitative information in addition to statistical grouping methods and some mapping techniques (Radu et al., 2021; Sharma et al., 2018).

VOSviewer is a tool that allows you to build and view bibliometric networks by using the "distance-based" technique where the nodes are positioned in such a way that the distance between them indicates a relation of proximity (J. Van Eck \& Waltman, 2020; Zhao et al.,
2020). Bibliometric analysis makes it possible to highlight pieces of information from organized literature and identify bibliometric dimensions related to coauthorship, citation, bibliographic coupling, and cocitation (Martinho \& Mourão, 2020).

The technique of clustering in unsupervised clusters and the recognition of patterns are very sensitive, the input parameters for the validation of the algorithm based on the clustering (Guadalupe \& León, 2019; Vagner et al., 2021), are frequently used in exploratory data analysis to extract the natural structure of the data (Lange et al., 2019; X. Wang et al., 2020). Network visualizations can help reveal complex and hidden patterns in textual sources (Düring, 2020). Our attention is focused on colors and patterns (Tableu, 2020), while for the building of bibliometric maps, we distinguish the maps and their representation (Radu et al., 2021; N. Van Eck \& Waltman, 2016).

The usefulness of the Thesaurus model in the worldwide use of records with keywords, and improved search retrieval in databases (Elsevier, 2020), translate into improvements in the methodology of fractional counting of citations and grouping of the variable level with a maximum limit of group size (Amirbagheri et al., 2019; Guadalupe \& León, 2019). For example, the number of authors, citations or references of a publication (Perianes et al., 2016). Likewise, the $h$ index, proposed to characterize the scientific production of a researcher (Estrada-Cuzcano \& Alhuay-Quispe, 2020; Laengle et al., 2021) is the balance between the number of publications and the citations to these (Laengle et al., 2021; Wikipedia, 2020)

This article contributes to the creation of bibliometric knowledge related to agricultural value chains, considering the little bibliometric information on the subject, especially in South American countries. It can be used as a source for the formulation and monitoring of the subject, in addition to the knowledge and analysis of the existing bibliographic sources in open access databases to contribute to research.

The objective for this work is the analysis of bibliometric indicators between 2010 and 2020, based on the theme of agricultural value chains. In addition, we propose as a specific objective, the procurement of the research source and search criteria, in order to obtain a database that allows for the analysis of the information obtained from the research source and interpreting the information collected, with the purpose of analyzing the academic production that it is generated worldwide, by countries, organizations and authors.

With the aforementioned background, the authors describe the research hypothesis as: There is enough theoretical or applied information researched about agricultural value chains in South American countries.

This study used publications and data obtained from the Web of Science (WOS), subsequently using VOSviewer to map the data graphically for the co- 
occurrence of bibliographic connections. The document is structured by sections: the following section describes the methodology and the data used; then, the bibliometric analysis in the next section shows the general trend, before discussing collaborative networks. Finally, the last section belongs to discussion and conclusions regarding other areas of research.

\section{Materials and methods.}

This study aims to identify the main research actors in agricultural value chains, taking into account that, in the world, a variety of links are formed and grouped around agricultural activity. The different activities associated with the living conditions of farmers, producers and consumers, have a contribution to the study of value chains. To understand the trends and research perspectives in this scientific field, it is important to know the main features and structure of the current trend (Pérez González \& Lutsak Yaroslava, 2017). Research analysis was done through "WOS". The VOSviewer software tool version 1.6.15 was chosen, since it is a free, functional, updated software for processing networks and obtaining the behavior of bibliometric indicators in the study period. Networks can include, for example, journals, research, individual publications, and build co-occurrences in keywords or co-authorship relationships from citations. The problem and motivation for this work are summarized in the following problem question: What is the information trend of the agricultural value chain worldwide?

In the preparation and visualization of the map of common expressions, it is necessary to distinguish the identification of the keywords. We later use a filter of nominal phrases, which are called terms (Ferasso et al., 2020; B. Wang et al., 2019).

For the analysis of information and generation of results, aspects related to qualitative and quantitative analysis are considered. Thus, in the initial stage, information from records such as: author, addresses, times cited, number of references cited, language, keywords, access number, open access, research area, among others, is considered and the database obtained is downloaded. Subsequently, the data are migrated to the VOSviewer software, where the processing of scientific information, analysis and visualization of the indicators is finally achieved, by obtaining the graphs that show the results of the objectives set.

\section{Analysis and results}

The research is presented in a general way according to the types of documents related to agricultural value chains entered in the WOS database in the Main Collection of Web of Science, with the terms "agriculture value chain". A systematic review was carried out. We obtained a total of 1,669 records from the date and year of publication according to the analysis period. It should be mentioned that all the documents in the sample maintain a Digital Object Identifier DOI or unique identifier of electronic publications. Most of the documents are journal articles or are part of book chapters 1660 , in revision 6 , editorial material 3. This indicates that published scientific articles are the main mode of scientific communication regarding agricultural value chains. The works were written mainly in English, with $94.85 \%$.

From the summary report generated by searching for "agriculture value chain" in WOS, it was observed that during the period of analysis, of the total of 1,669 records, these were cited 21,979 times in different elements indexed within the main WOS Collection, having an average of 14.27 citations for each element and reaching an h- index of 63.

Within WOS there are 111 visualization categories or research areas for this work. The ten predominant categories in publications are: environmental science with 359, agricultural economics policy with 211, economics with 194, multidisciplinary agriculture with 148 , green and sustainable science technology with 145 , environmental studies with 140, food science technology with 134, agronomy with 101, environmental engineering with 95 , and administration with 79 .

Regarding the research, WOS groups the areas related to the present work into 60 research areas, of which agriculture represents $31 \%$, ecology of environmental sciences $26 \%$, economic business with $17 \%$, science technology and other topics $11 \%$, engineering $10 \%$, and the remaining areas $5 \%$.

The annual production of research between 2010 and 2020 , according to the information collected, is as follows. By 2010, 62 publications were registered; this number increased progressively until 2013 with 100 publications, suffering a slight fall in 2014 with 88 records, managing to recover and reaching 2020 with 273 records - a considerable increase.

Regarding high impact authors within the WOS records, as shown in Table 1: the author with the highest number of records is Klerkx L, who published 9 articles and represents a value of $0.54 \%$. The next four authors were Hellin J, Bijman J, Bonney L, Poole N with a number of records of 7, 6, 6 and 6 for each of the authors respectively. 
Table 1 Top 15 High Impact Authors

Tab.1

\begin{tabular}{clcc}
\hline \# & Authors & $\begin{array}{c}\text { Number of } \\
\text { records }\end{array}$ & $\begin{array}{c}\% \\
\text { of } 1,669\end{array}$ \\
\hline 1 & Klerkx L & 9 & $0.54 \%$ \\
2 & Hellin J & 7 & $0.42 \%$ \\
3 & Bijman J & 6 & $0.36 \%$ \\
4 & Bonney L & 6 & $0.36 \%$ \\
5 & Poole N & 6 & $0.36 \%$ \\
6 & Swinnen J & 6 & $0.36 \%$ \\
7 & Wang J & 6 & $0.36 \%$ \\
8 & Yan B & 6 & $0.36 \%$ \\
9 & Bellemare MF & 5 & $0.30 \%$ \\
10 & Dentoni D & 5 & $0.30 \%$ \\
11 & Durr J & 5 & $0.30 \%$ \\
12 & Fasse A & 5 & $0.30 \%$ \\
13 & Glasbergen P & 5 & $0.30 \%$ \\
14 & Graef F & 5 & $0.30 \%$ \\
15 & Lambin Ef & 5 & $0.30 \%$ \\
\hline
\end{tabular}

Source: From WOS data Prepared by: Author.

The organization-based distribution of research results can help to understand the research capacity and activities of organizations around the world, thus identifying leadership in agricultural value chain research. An important component in bibliometric networks is the evaluation of citations applying an analysis of the most influential and cited organizations or universities. The analysis reveals the level of affinity of organizations based on the number of records. Consequently, the twenty most cited organizations in the agricultural value chain research domain are presented in Table 2. Organizational production is headed by Wageningen Univ, with 55 records. The following four organizations were: Chinese Acad Sci, Int Food Policy Res Inst, Univ Ghent, Cornell Univ.

Table 2. Top 20 Main Organizations Tab. 2

\begin{tabular}{llll}
\hline$\#$ & Field: Organizations & $\begin{array}{l}\text { Number } \\
\text { records }\end{array}$ & $\begin{array}{l}\text { \% } \\
1669\end{array}$ \\
\hline 1 & Wageningen Univ & 55 & $3.30 \%$ \\
2 & Chinese Acad Sci & 26 & $1.56 \%$ \\
3 & Int Food Policy Res Inst & 24 & $1.44 \%$ \\
4 & Univ Ghent & 18 & $1.08 \%$
\end{tabular}

\begin{tabular}{|c|c|c|c|}
\hline 5 & Cornell Univ & 17 & $1.02 \%$ \\
\hline 6 & Univ Hohenheim & 17 & $1.02 \%$ \\
\hline 7 & Int Livestock Res Inst & 16 & $0.96 \%$ \\
\hline 8 & Michigan State Univ & 16 & $0.96 \%$ \\
\hline 9 & Univ Copenhagen & 16 & $0.96 \%$ \\
\hline 10 & Wageningen Univ Res & 16 & $0.96 \%$ \\
\hline 11 & Humboldt Univ & 15 & $0.90 \%$ \\
\hline 12 & Univ Bonn & 15 & $0.90 \%$ \\
\hline 13 & Univ Queensland & 15 & $0.90 \%$ \\
\hline 14 & Swedish Univ Agr Sci & 14 & $0.84 \%$ \\
\hline 15 & Cirad & 13 & $0.78 \%$ \\
\hline 16 & Penn State Univ & 11 & $0.66 \%$ \\
\hline 17 & Univ Calif Davis & 11 & $0.66 \%$ \\
\hline 18 & Univ New England & 11 & $0.66 \%$ \\
\hline 19 & Zhejiang Univ & 11 & $0.66 \%$ \\
\hline 20 & Univ Illinois & 10 & $0.60 \%$ \\
\hline
\end{tabular}

Source: From WOS data. Prepared by: Author.

The keywords and their origin by country were considered for the process of generating visual information through results graphics, given the greater frequency in the records of the documents of the analyzed database. Through the graphic representations or visual maps found in the records, the aim is to show interesting results for the subject based on the cooccurrence of keywords.

Fig. 1 Display of keywords in WOS publications.

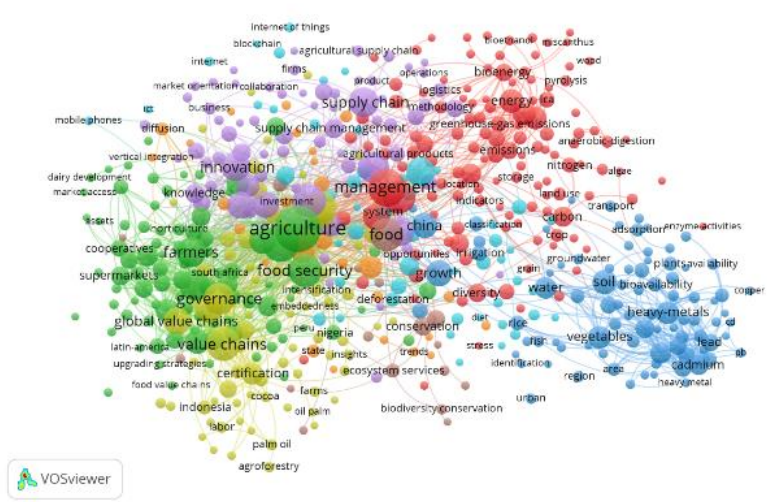

Source: From WOS data with VOSviewer support. Prepared by: Author.

The observed distance between nodes shows the relationship between them; that is, the smaller the distance, the greater the relationship. Network connections show the keywords that appear together most frequently in posts. The higher the frequency of presence, the greater the circle. Finally, the color of the 
node indicates the relationship between research areas and those associated with a political geographic area. The relevant trends can be extracted in the analysis with the nomenclature regarding the territorial positioning of the research. Thus, we find Europe, Asia, North America and China show an interest in agricultural value chains.

Fig. 2 Network of keywords in agricultural value chains publications.

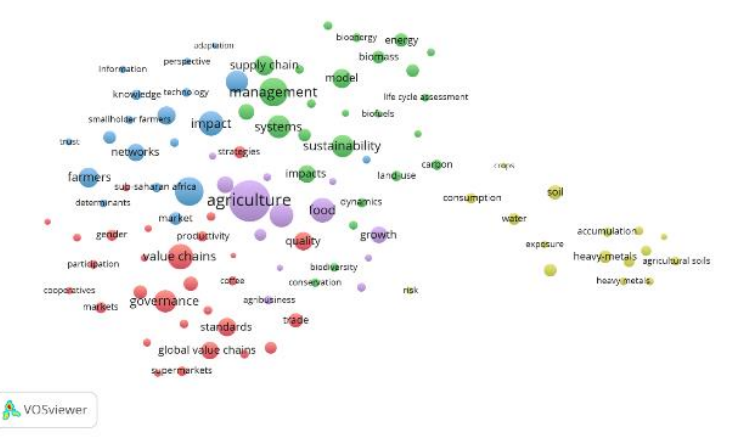

Source: From WOS data with VOSviewer support. Prepared by: Author.

To create the relationship graph and identify the most used keywords in research, we focused on value chains using VOSviewer. Graph 2 shows the most used keywords are "agriculture", followed by "management", "value chains", "impact" and "governance", based on the number of times they are used in the database records of data analyzed. It can be seen that, among the top 20 keywords, some are related to food and business, such as "nutrition", "quality", "consumption", "energy"; "systems", "growth", "model", "poverty". There are also keywords related to the social sphere, such as "gender", "farmers", "smallholder farmer". In addition, the graph shows the formation of five conglomerates or clusters of the words that have the greatest impact.

The analysis of the occurrence of terms, after the normalization process and the frequency threshold $(\mathrm{n}>$ 1) was reduced to 101 keywords in the records, which are represented by colors in five clusters as shown in figure 1. The keywords identifying the topics in the publications show the weight of appearance in the count through the size of each term. Thus, the first purple cluster is made up of 13 items, the five most frequent are as follows: "agriculture", "food", "growth", "integration" and "nutrition". In the red cluster, made up of 29 items, five toponyms are seen as predominant: "value chains", "governance", "global value chain", "standards" and "gender". The third group in green is made up of 24 items, such as: "management", "systems", "supply chain", "sustainability model". The light blue cluster, made up of 18 items, is the most common: "farmers", "impact", "networks", "smallholder farmers" and "sub-saharan Africa". Finally, the yellow cluster shows the five most frequent items: "agricultural soils", "consumption", "heavy metal", "soil" and "water".

The elements in this research show the amount of elements involved in the different agricultural productive links, and the effects they can cause on the environment, as well as social, economic, environmental, ecological, and political aspects framed in the development of the populations where the world's food is produced. Finally, it can be seen that the agricultural products related to the subject that attract attention are coffee, corn and some unspecified vegetable products.

Fig 3. Countries conducting research on agricultural value chains.

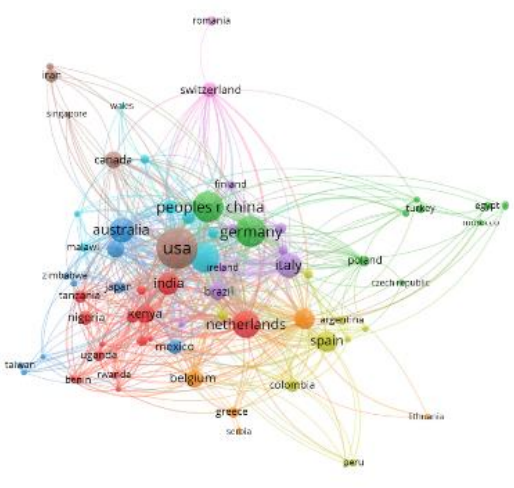

Source: From WOS data with VOSviewer support Prepared by: Author.

The analysis of country records related to agricultural value chains can help us to understand the capacity of a country for scientific production as shown in figure 3 . A total of 126 countries contributed to the scientific and academic production in agricultural value chains. As shown in figure 3, the size of the circles is proportional to the number of items. Thus, we see that the countries that contribute the most to this subject are the United States, England, Denmark, Germany and France. In addition, countries such as the United States, the People's Republic of China, Ireland, Australia and Germany have greater influence. There is a geographical closeness between these last three countries, and there is also a scientific closeness among them in relation to the United States: they are politically and geographically distant, but they are intellectually related. This contrasts with the geographical closeness between Germany and Italy, which is demonstrated on the graph. These research aims at improving efficiency in the quality of agricultural value chains. 
Fig. 4. Network of articles on agricultural value chains in terms of countries of the American continent.

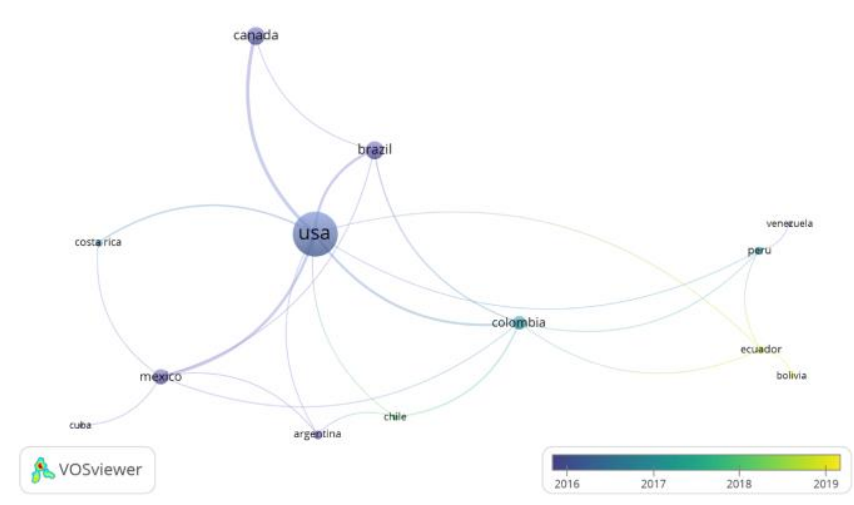

Source: From WOS data with VOSviewer support Prepared by: Author.

As can be seen in Figure 4, the size of the nodes and the research work correspond to the weights of the nodes, that is, the larger the node and the word, the greater the weight. The distance between the nodes reflects the relationship that exists between them. The thicker the line, the greater the occurrence, as can be seen in the previous figure. The frequency and strength of the countries with the greatest representation in research on agricultural value chains in the American continent according to the WOS report are the United States, Canada, Brazil and Mexico. Thus, the annual contribution of the countries can also be appreciated according to the color of the curves. We can also observe the initial contribution of countries such as Ecuador, Bolivia, Argentina and Peru that, as of 2019, are just beginning to publish research on this topic.

\section{Discussion and conclusions}

In this research, with a broad approach and relationship with different research areas, 111 categories are denoted, especially related to the agricultural, environmental and economic aspects. Compared to a bibliometric study of Covid-19 using a Scopus database, the documents were classified into four different areas: health sciences, physical sciences, life sciences, social sciences, and humanities (Amirbagheri et al., 2019; Aristovnik et al., 2020); possibly due to the relevance of the issue related to the pandemic and the search for the vaccine and health effects.

In the parametric analysis of the bibliometric data for the keywords and the analysis of citations used in the evaluation of the quality of publications in scientific, technological and social science journals, a total of
15,400 keywords were obtained in a research of smart cities (Yi-Ming et al., 2019). In the present study, a total of 8,375 keywords are shown to have a relationship with and an impact related to agricultural value chains.

According to Medina-Mijangos \& Seguí-Amórtegui, (2020), the study on municipal solid waste management using WOS mentions the importance of the types of waste and the keywords "packaging waste" and their environmental and economic impact, as a way to manage university social responsibility. Similarly, in our study, words such as "agriculture" and agricultural "value chains", "simple, supply" and "global" predominate, which focus on different environmental, economic and agricultural areas.

The growing academic interest in the search for problems related to networks identifies 1,863 records for the phrase "sustainable supply chain" in Scopus, and 1,182 in WOS, which served to map the scientific landscape of this topic (Lis et al., 2020). These values are similar to those obtained in this research with 1,669 records. However, when collecting the information from WOS, Scopus and Google Scholar Metrics on Circular Economy (Enric Camón \& Celma, 2020), values of $3,391,1,901$ and 36,300 records respectively were registered; to compare the metrics based on bibliographic reference managers, which obtained considerable differences possibly due to the subject and the evaluation period.

Regarding the affiliation of researchers by countries on the subject of sustainable tourism worldwide, there are 122 countries, with the United States being the one that contributes $10.10 \%$, out of a total of 415 records. This suggests the issue attracts the attention of authors from many countries (Niñerola et al., 2019) worldwide. Regarding the research, a global result of 126 countries was obtained, the top contributors being the United States with 268 records, England with 204, Denmark with 189, Germany with 160, and France with 113. These countries' contribution in terms of connections on the subject is probably due to them being large agricultural producers. Something similar happens with the contribution of scientific articles related to agricultural value chains.

Sample delimitations can be the selected publication period, geographical location of the authors, research area, journal sample or keywords, among others. From the WOS Collection, from 2005 to 2014, a sample of 453 papers with a total of 9,207 citations was distributed in the bioeconomy analysis period (Bugge et al., 2016; Mondal et al., 2019). Meanwhile, in the present study, a sample of 1669 publications were obtained with 21,979 citations with a longer period of time, and possibly the same geographic location.

Regarding publications by country, the study of bibliometric analysis of articles on Islamic economics and finance by Indonesian authors has a sample of 559 articles published in Indonesia. Almost half were 
published in 24 journals, the most popular journal being Talent Developments and Excellence, with 35 articles related to Scimago classification (Handoko, 2020). In the present study, Indonesia has a sample of 19 publications, values lower than those shown by South American countries such as Brazil with 49 publications, Colombia with 28 , but higher than those shown by countries such as Argentina with 13 publications, Peru with 10, Chile with 7 and Ecuador with 6, in several scientific journals, possibly due to the research conditions on the subject and the economic conditions of the study.

In a study carried out on integrated combined solar cycles based on data analysis, Reyes-Belmonte (2020) obtained an average total of 15 citations per publication, in a period from 2000 to 2018. For comparison, this study yields a value mean of 14.27 , with no significant variation between the research areas despite the relevance of the study today and the similarity of the analysis periods.

Using the InOrdinatio equation to classify the articles in order of relevance according to the Journal Citations Reports (JCR) impact factor and the criterion for choosing the most relevant articles, a sample of 39 articles was obtained for the bibliographic portfolio on smart cities (De Souza et al., 2019). Also, in the present research, the organizations that report the highest number of citations are Wageningen University with 984 citations, far behind Cornell University with 455, Columbia University with 376 and Chinese Academic Science with 274 citations. The latter, despite being the second in publications with 25 records, is surpassed in citations by Columbia University, which has 6 publications and its network of citations includes the World Bank and the international research organization on corn and wheat improvement (int maize \& wheat improvement).

Based on the analysis of bibliometric indicators of the publications in WOS applied to our research of agricultural value chains, the document shows the trends from a general perspective through the articles that analyze aspects of the subject. The importance of the document is that even at the moment, there are no bibliometric studies analyzing aspects related to agricultural value chains. Another point to consider is the methodology to analyze the external impact. What is evidenced by the bibliometric analysis of the subject and, in general, the increase in research related to the agricultural value chain since 2014 , is that a trend that leads to a sustainable development of agriculture, is becoming a potential research area in each country, in addition to the relevance for the improvement in the quality of life of the actors and their environment, as a measure to mitigate the pollution of natural resources. Given that the livelihood of the world population depends on the production of agricultural products and by-products, it is expected that research will continue to increase mainly in countries identified in the present study and publications increase in underdeveloped countries. In addition, this subject is related to the goals and objectives of sustainable development set by the United Nations for 2030.

The importance of the subject serves as a guide for decision makers, since the results can help them find samples of the economic, social, ecological systems and the process evaluation methodology, and therefore make better decisions. Local governments should also consider the possibility of making agricultural policies, regulations based on socioeconomic results to increase or decrease the use of external technologies, and the improvement of management systems. The research visualized a series of organization networks that describe the relationships between various scientific domains that contribute to the connection between natural, agricultural, environmental, social, economic and political sciences. It is important to evaluate bibliometric techniques not only for research fields but for the specific scope of agricultural value chains.

In the political-administrative sphere, it is urgent to increase commitment to agricultural value chains, in order to improve the economy of South American producers, with the aim of replicating and promoting public policies. It is also important to encourage the search for information on elements that promote the consumption of non-traditional agricultural products in consumers, in addition to knowing what they consume. Encouraging competitive companies that make a profit to research in communities can also be beneficial. The dataset that was used for the visualizations requires knowledge of the context to be meaningful, data coding and knowledge of the scope to make sense of the graphs. For the future, it is recommended that the search for records be expanded by using other databases, comparative analysis of the number of results in pillars such as agricultural sustainability, agricultural economics.

According to the results obtained, it can be observed that South American countries have little or almost no research related to the subject. This research contributes to improving the value chains and the livelihoods of the social actors involved

Thanks.

The author wishes to thank the Librarianship group of the Teaching and Learning and Research and Academic Publication Area of the Pontificia Universidad Católica de Chile, for the support in the academic training spaces in the use of the VOSviewer software. 


\section{References}

Akinlolu, M., Haupt, T. C., Edwards, D. J., \& Simpeh, F. (2020). A bibliometric review of the status and emerging research trends in construction safety management technologies. International Journal of Construction Management, $\quad 0(0), \quad 1-13$. https://doi.org/10.1080/15623599.2020.1819584

Amirbagheri, K., Núñez-Carballosa, A., Guitart-Tarrés, L., \& Merigó, J. M. (2019). Research on green supply chain: a bibliometric analysis. Clean Technologies and Environmental Policy, 21(1), 322. https://doi.org/10.1007/s10098-018-1624-1

Ardanuy, J. (2009). Breve introducción a la bibliometría. Universitat de Barcelona, 63. https://doi.org/10.1038/nmat3485

Aristovnik, A., Ravšelj, D., \& Umek, L. (2020). A bibliometric analysis of covid-19 across science and social science research landscape. Sustainability (Switzerland), 12(21), 1-30. https://doi.org/10.3390/su12219132

Baier-Fuentes, H., Cascón-Katchadourian, J., Sánchez, Á. M., Herrera-Viedma, E., \& Merigó, J. (2018). A Bibliometric Overview of the International Journal of Interactive Multimedia and Artificial Intelligence. International Journal of Interactive Multimedia and Artificial Intelligence, $5(3)$,

https://doi.org/10.9781/ijimai.2018.12.003

Baranauskas, G., Raišienè, A. G., \& Korsakienè, R. (2020). Mapping the Scientific Research on Mass Customization Domain: A Critical Review and Bibliometric Analysis. Journal of Risk and Financial Management, 13(9), 220. https://doi.org/10.3390/jrfm13090220

Barrios Guzman, L., Cárdenas Escorcia, Y., \& Valencia Ochoa, G. (2017). Análisis tendencial de las investigaciones de eficiencia energética en sistemas de refrigeración durante los años 2013 a 2017. Espacios, 38(54).

Bugge, M. M., Hansen, T., \& Klitkou, A. (2016). What is the bioeconomy? A review of the literature. Sustainability (Switzerland), 8(7). https://doi.org/10.3390/su8070691

De Las Heras, C., Martel, T., \& Jambrind, C. (2018). Análisis de las redes académicas y tendencias científicas de la comunicación en las universidades españolas. Revista Prisma Social, 22, 229-246.

De Souza, J., De Francisco, A. C., Piekarski, C. M., \& do Prado, G. F. (2019). Data mining and machine learning to promote smart cities: A systematic review from 2000 to 2018. Sustainability (Switzerland), 11(4). https://doi.org/10.3390/su11041077

Düring, M. (2020). De la hermenéutica a las redes de datos: Extracción de datos y visualización de redes en fuentes históricas. https://doi.org/10.46430/phes0002

Elleby, C., Perez, I., Adenauer, M., \& Genovese, G. (2020). Impacts of the COVID-19 Pandemic on the Global Agricultural Markets. https://doi.org/doi: 10.1007/s10640-020-00473-6

Elsevier. (2020). Scopus. Content coverage guide (pp. 1-24). https://www.elsevier.com/_data/assets/pdf_file/0017/114533/Scop us GlobalResearch Factsheet2019 FINAL_WEB.pdf

Enric Camón, L., \& Celma, D. (2020). Circular economy. A review and bibliometric analysis. Sustainability (Switzerland), 12(16). https://doi.org/10.3390/SU12166381

Estrada-Cuzcano, A., \& Alhuay-Quispe, J. (2020). Aproximación bibliométrica a la Revista de Comunicación (Perú), 2002-2019. Revista de Comunicación, 19(2), 111-124. https://doi.org/10.26441/rc19.2-2020-a6

Fabregat-Aibar, L., Barberà-Mariné, M. G., Terceño, A., \& Pié, L. (2019). A bibliometric and visualization analysis of socially responsible funds. Sustainability (Switzerland), 11(9). https://doi.org/10.3390/su11092526

Ferasso, M., Beliaeva, T., Kraus, S., Clauss, T., \& Ribeiro-Soriano, D. (2020). Circular economy business models: The state of research and avenues ahead. Business Strategy and the Environment, May, 3006-3024. https://doi.org/10.1002/bse.2554

Food and Agriculture Organization - FAO. (2019). El trabajo de la FAO en la agricultura familiar. Prepararse para el Decenio Internacional de Agricultura Familiar (2019-2028) para alcanzar los
ODS. FAO. http://www.fao.org/3/ca1465es/CA1465ES.pdf Garrigos-Simon, F. J., Narangajavana-Kaosiri, Y., \& LenguaLengua, I. (2018). Tourism and sustainability: A bibliometric and visualization analysis. Sustainability (Switzerland), 10(6), 1-23. https://doi.org/10.3390/su10061976

González-Torres, T., Rodríguez-Sánchez, J. L., Montero-Navarro, A., \& Gallego-Losada, R. (2020). Visualizing Research on Industrial Clusters and Global Value Chains: A Bibliometric Analysis. $\begin{array}{llll}\text { Frontiers in Psychology, } & 11(\mathrm{July}), & 1-14 .\end{array}$ https://doi.org/10.3389/fpsyg.2020.01754

Govindan, K., \& Soleimani, H. (2017). A review of reverse logistics and closed-loop supply chains: a Journal of Cleaner Production focus. Journal of Cleaner Production, 142(March 2017), 371-384. https://doi.org/10.1016/j.jclepro.2016.03.126

Guadalupe, T., \& León, J. (2019). Factores asociados a la evolución de clusters en México: Validación de un instrumento para su caracterización.

https://www.semanticscholar.org/paper/FACTORES-ASOCIADOSA-LA-EVOLUCIÓN-DE-CLUSTERS-EN-DE-Bustamante-

Balderramaa/d443b9818bbceb1cb48c6bbe63a1df03c37d1dd5

Handoko, L. H. (2020). Bibliometric analysis and visualization of islamic economics and finance articles indexed in scopus by Indonesian authors. Science Editing, 7(2), 169-176. https://doi.org/10.6087/KCSE.213

Hasbullah, N. N., Sulaiman, Z., Mas'od, A., \& Ahmad, S. N. (2021). Bibliometric analysis of sustainable and green consumption research from 1974 to 2019. Turkish Journal of Computer and Mathematics Education, 12(5), 1292-1301. https://doi.org/10.17762/turcomat.v12i5.1796

Hong, T., Feng, X., Tong, W., \& Xu, W. (2019). Bibliometric analysis of research on the trends in autophagy. PeerJ, 2019(6), 1-15. https://doi.org/10.7717/peerj.7103

Janmaijaya, M., Shukla, A. K., Abraham, A., \& Muhuri, P. K. (2018). A scientometric study of neurocomputing publications (1992-2018): An aerial overview of intrinsic structure. Publications, 6(3). https://doi.org/10.3390/publications6030032

La Paz, A., Merigó, J. M., Powell, P., Ramaprasad, A., \& Syn, T. (2020). Twenty-five years of the Information Systems Journal: A bibliometric and ontological overview. Information Systems Journal, 30(3), 431-457. https://doi.org/10.1111/isj.12260

Laengle, S., Lobos, V., Merigó, J. M., Herrera-Viedma, E., Cobo, M. J., \& De Baets, B. (2021). Forty years of Fuzzy Sets and Systems: A bibliometric analysis. Fuzzy Sets and Systems, 402, 155-183. https://doi.org/10.1016/j.fss.2020.03.012

Lange, T., Roth, V., Braun, M., \& Buhmann, J. (2019). Stability based validation of clustering solutions (p. 288). https://doi.org/10.1162/089976604773717621

Lei, N., Faust, O., Rosen, D. W., \& Sherkat, N. (2018). Uncovering design topics by visualizing and interpreting keyword data. Proceedings of International Design Conference, DESIGN, 1, 5768. https://doi.org/10.21278/idc.2018.0370

Li, Y., Xu, Z., Wang, X., \& Filip, F. G. (2019). Studies in informatics and control: A bibliometric analysis from 2008 to 2019. International Journal of Computers, Communications and Control, 14(6), 633652. https://doi.org/10.15837/ijccc.2019.6.3753

Lis, A., Sudolska, A., \& Tomanek, M. (2020). Mapping research on sustainable supply-chain management. Sustainability (Switzerland), 12(10). https://doi.org/10.3390/SU12103987

Llorent-Bedmar, V., \& Sianes-Bautista, A. (2018). Claves para publicar en revistas educativas JCR en alemán, inglés y español. Chasqui. Revista Latinoamericana de Comunicación, 0(137), 349365. https://doi.org/10.16921/chasqui.v0i137.3073

Maier, D., Maier, A., Aşchilean, I., Anastasiu, L., \& Gavriş, O. (2020). The relationship between innovation and sustainability: A bibliometric review of the literature. Sustainability (Switzerland), 12(10). https://doi.org/10.3390/SU12104083

Malanski, P. D., Dedieu, B., \& Schiavi, S. (2020). Mapping the research domains on work in agriculture. A bibliometric review from Scopus database. Journal of Rural Studies. 
https://doi.org/10.1016/j.jrurstud.2020.10.050

Martinho, V. D., \& Mourão, P. R. (2020). Circular economy and economic development in the European Union: A review and bibliometric analysis. Sustainability (Switzerland), 12(18). https://doi.org/10.3390/SU12187767

Mas-Tur, A., Guijarro, M., \& Carrilero, A. (2019). The influence of the circular economy: Exploring the knowledge base. Sustainability (Switzerland), 11(16). https://doi.org/10.3390/su11164367

Medina-Mijangos, R., \& Seguí-Amórtegui, L. (2020). Research trends in the economic analysis of municipal solid waste management systems: A bibliometric analysis from 1980 to 2019 . Sustainability $\quad$ (Switzerland), $12(20), \quad 1-20$. https://doi.org/10.3390/su12208509

Mondal, D., Chakrabarti, B., \& Maity, A. (2019). Publications output of the Indian association for the cultivation of science during 20082017: A scientometric assessment. DESIDOC Journal of Library and Information Technology, 39(5), 244-250. https://doi.org/10.14429/djlit.39.5.14572

Morton, J. (2020). On the susceptibility and vulnerability of agricultural value chains to COVID-19. https://doi.org/10.1016/j.worlddev.2020.105132

Niñerola, A., Sánchez-Rebull, M. V., \& Hernández-Lara, A. B. (2019). Tourism research on sustainability: A bibliometric analysis. Sustainability (Switzerland), $\quad 11(5), \quad 1-17$. https://doi.org/10.3390/su11051377

Pérez González, M., \& Lutsak Yaroslava, N. (2017). La producción científica sobre la innovación social para el desarrollo local. Una revisión bibliométrica. Revista Prisma Social, O(19), 146-182.

Perianes, A., Waltman, L., \& Jan van, N. (2016). Constructing bibliometric networks: A comparison between full and fractional counting. Journal of Informetrics, 10(4), 1178-1195. https://doi.org/10.1016/j.joi.2016.10.006

Radu, V., Radu, F., Tabirca, A. I., Saplacan, S. I., \& Lile, R. (2021). Bibliometric Analysis of Fuzzy Logic Research in International Scientific Databases. International Journal of Computers, Communications and Control, 16(1), 1-20. https://doi.org/10.15837/ijccc.2021.1.4120

Repanovici, R. M., \& Nedelcu, A. (2018). 3D printing new direction and collaboration in scientific research. A scientometric study using Web of Science, Clarivate Analytics database. MATEC Web of Conferences, 178, 3-8. https://doi.org/10.1051/matecconf/201817807009

Reyes-Belmonte, M. Á. (2020). A bibliometric study on integrated solar combined cycles (ISCC), trends and future based on data analytics tools. Sustainability (Switzerland), 12(19). https://doi.org/10.3390/su12198217

Sahle, M., Yeshitela, K., \& Saito, O. (2018). Mapping the supply and demand of Enset crop to improve food security in Southern Ethiopia. Agronomy for Sustainable Development, $38(1)$. https://doi.org/10.1007/s13593-017-0484-0

Sharma, N., Bairwa, M., Gowthamghosh, B., Gupta, S. D., \& Mangal, D. K. (2018). A bibliometric analysis of the published road traffic injuries research in India, post-1990. Health Research Policy and Systems, 16(1), 1-11. https://doi.org/10.1186/s12961-018-02989

Tableu. (2020). Guía de visualización de datos: definición, ejemplos $y$ recursos de aprendizaje. https://www.tableau.com/eses/learn/articles/data-visualization

Trapala, J., Bustos, I., Manzanares, P., BaÁjrzana, E., \& Montiel, C. (2020). Protein Expression and Purification. Protein Expression and Purification, 176 , 105718.

https://doi.org/https://doi.org/10.1016/j.pep.2020.105718

Vagner, L., Valaskova, K., Durana, P., \& Lazaroiu, G. (2021). Earnings management: A bibliometric analysis. Economics and Sociology, 14(1), 249-262. https://doi.org/10.14254/2071789X.2021/14-1/16

Van Eck, J., \& Waltman, L. (2020). VOSviewer Manual. Universiteit Leiden, 1(April), 24.

Van Eck, N., \& Waltman, L. (2016). Text Mining and Visualization.
Universiteit Leiden, 1-5. https://doi.org/10.1201/b19007

Wang, B., Xing, D., Zhu, Y., Dong, S., \& Zhao, B. (2019). The State of Exosomes Research: A Global Visualized Analysis. BioMed Research International, 2019. https://doi.org/10.1155/2019/1495130 Wang, X., Xu, Z., \& Škare, M. (2020). A bibliometric analysis of Economic Research-Ekonomska Istraživanja (2007-2019). Economic Research-Ekonomska Istrazivanja , 33(1), 865-886. https://doi.org/10.1080/1331677X.2020.1737558

Wikipedia. (2020). Índice_h. https://es.wikipedia.org/wiki/Índice_h Yi-Ming, G., Zhen-Ling, H., Guo, J., Li, H., Xing-Rong, G., \& Nkeli, M. J. (2019). Bibliometric analysis on smart cities research. Sustainability (Switzerland),

https://doi.org/10.3390/su11133606

Zhao, Z., Tang, X., Mu, X., \& Zhao, H. (2020). Bibliometric analysis of the 100 most cited articles on cervical cancer radiotherapy. Medicine, 99(40),

e22623. 